\title{
Antioxidant and antitopoisomerase activities in plant extracts of some Colombian flora from La Marcada Natural Regional Park
}

\author{
Jaime Niño ${ }^{1}$, Yaned Milena Correa ${ }^{2}$, Germán David Cardona $^{1} \&$ Oscar Marino Mosquera $^{1}$ \\ 1. Grupo de Biotecnología-Productos Naturales, Escuela de Tecnología Química, Universidad Tecnológica de Pereira, \\ Pereira, Colombia; janino@utp.edu.co, paisa2106@hotmail.com, omosquer@utp.edu.co \\ 2. Grupo de Biotecnología-Productos Naturales, Departamento de Química, Facultad de Ciencias Exactas y Naturales, \\ Universidad de Caldas, Manizales, Colombia; yaned.correa@ucaldas.edu.co
}

\author{
Received 13-IX-2010. C Corrected 06-I-2011. Accepted 04-II-2011.
}

\begin{abstract}
Many plants have been used to treat some diseases and infections since time immemorial, and this potential has been exploited by the pharmaceutical industry in the search of new analgesic, anticarcinogenic and antimicrobial agents, among other active agents. In order to contribute with bioprospection studies on the Colombian flora, 35 extracts from 13 plant species belonging to seven families (Apocynaceae, Cactaceae, Costaceae, Eremolepidaceae, Passifloraceae, Solanaceae and Urticaceae) were collected from La Marcada Natural Regional Park (LMNRP), Colombia. Dichloromethane, $n$-hexane and aqueous-methanol crude extracts were prepared and evaluated for their activity against Saccharomyces cerevisiae RS322N, R52Y and RS321 strains in the yeast mutant assay and their antioxidant capacity through the DPPH test. The dichloromethane extract from Myriocarpa stipitata (Urticaceae) showed moderate inhibitory activity against the three S. cerevisiae strains tested. The capacity of the dichloromethane extract from M. stipitata to inhibit the enzyme topoisomerase I and to cause DNA damage was inferred from these results. In the DPPH assay, the $n$-hexane crude extract from Costus sp. (Costaceae) showed good antioxidant activity (48\%); in addition, the crude dichloromethane and aqueous-methanol extracts from Rhipsalis micrantha (Cactaceae) showed moderate antioxidant activity with percentage of 29 and 21\%, respectively. Rev. Biol. Trop. 59 (3): 1089-1097. Epub 2011 September 01.
\end{abstract}

Key words: DNA damage agent, DPPH, DNA topoisomerase inhibitors, Saccharomyces cerevisiae.

Many bioactive compounds and their derivatives have been shown to inhibit carcinogenesis in a number of experimental systems involving initiation, promotion and progression steps of this disease. Therefore, the discovery of novel naturally occurring anticarcinogens which would prevent, slow down and/ or reverse cancer induction and its subsequent development are of paramount importance to produce new effective medicines (Rajeshkumar et al. 2002).

DNA topoisomerases play important functions in transmission and expression of genetic information, because these enzymes carry out critical roles in DNA replication, transcription and recombination, as well as chromosome condensation and segregation (Colley et al. 2004). Two major classes of topoisomerase enzymes have been identified, type I and type II. The former one introduces one break, while the last type produces transient double strand breaks in DNA (Dong et al. 2000). Topoisomerase inhibitors constitute a class of chemopreventive agents that hamper carcinogenesis via their antiproliferative or cell-differentiating action (Ramirez-Mares et al. 2004). Antitopoisomerase drugs bind and stabilize the complex (DNA Topoisomerase) and the enzyme cannot relax (Zhang \& Siede 2003). In this manner, several studies have shown the usefulness of the yeast Saccharomyces cerevisiae Meyen ex E.C. Hansen as a model organism 
for characterization and screening of anticancer drugs with inhibitory properties against topoisomerases I and II (Simon et al. 2000, Niño et al. 2007).

On the other hand, in living organisms the reactive oxygen species (ROS) and reactive nitrogen species (RNS) are known to cause damage to lipids, proteins, enzymes and nucleic acids leading to cell or tissue injury, implicated in the processes of aging as well as in a wide range of degenerative diseases including inflammation, cancer, atherosclerosis, diabetes, liver injury, Alzheimer, Parkinson and coronary heart pathologies, among others (Moon \& Shibamoto 2009). However, cells have defence systems to protect and keep their cellular constituents in the right redox state; this includes two different pathways: enzymatic and non enzymatic ones. The former one includes enzymatic systems such as the superoxide dismutase, catalase, glutathione peroxidase, glutathione reductase and glutathione-S-transferase. In vivo, these antioxidant enzymes should have the proper equilibrium to reduce and to prevent ROS and RNS species generation within the cells and to protect cellular constituents from oxidative damage (Gasparri 2005). The non enzymatic one includes small antioxidant molecules like ascorbate, chlorogenic acids, polyunsaturated fatty acids, sugars and vitamin E, among others (Reddy et al. 2008).

Continuing with the bioprospection study on the flora from La Marcada Natural Regional Park (LMNRP, Risaralda, Colombia) as a source of new secondary metabolites with diverse grade of biological activities and taking in consideration the fact that there is still great interest in finding novel and better inhibitory agents against topoisomerases or with antioxidant activities, prompted us to screen $n$-hexane, dichloromethane and aqueous-methanol crude extracts belonging to the selected families collected to study these activities.

\section{MATERIAL AND METHODS}

Plant material: The adult aerial plant samples (leaves and branches) used for this study were collected in June-July 2005 in La Marcada Natural Regional Park (LMNRP, Colombia) with an altitudinal range between 1600-2 000m.a.s.1., a temperature variation between $16-22^{\circ} \mathrm{C}$ and an average rainfall of $2464 \mathrm{~mm} /$ year. The plants were identified taxonomically by Dr. F.J. Roldán and a voucher specimen for each plant material was deposited at the University of Antioquia Herbarium, Medellín, Colombia (Table 1).

Plant samples (Table 1) were oven dried at $50^{\circ} \mathrm{C}$ for $48 \mathrm{~h}$, the dry materials were ground to a fine powder and aliquots of $300 \mathrm{~g}$ were extracted by maceration with $900 \mathrm{~mL}$ of methanol (three times each). Then, the solvent was pulled out and concentrated to dryness in a rotary evaporator at $45^{\circ} \mathrm{C}$. A total of $25 \mathrm{~g}$ of each concentrated methanol extract was dissolved in $100 \mathrm{~mL}$ of a mixture of methanolwater $(2: 8)$ and were successively partitioned with $300 \mathrm{~mL}$ of $n$-hexane and dichloromethane to obtain the $n$-hexane, dichloromethane and aqueous-methanol extracts, for each plant. The different extracts were concentrated to dryness at reduce pressure and stored at $-10^{\circ} \mathrm{C}$ until assayed.

In this study, the solvents $n$-hexane, dichloromethane, dimethylsulfoxid (DMSO), methanol and ethanol (analytical grade) were purchased from Mallinckrodt (Phillipsburg, NJ, USA). 1,1-diphenyl-2-picrylhydrazyl (DPPH), Nystatine and D-glucose were obtained from Sigma-Aldrich (St. Louis, MO, USA). Yeast extract, peptone and agar were acquired from Oxoid (Basingtoke, United Kingdom). Silica gel plates $\left(\mathrm{F}_{254} 0.2 \mathrm{~mm}\right.$ layer thickness) were purchased from Merck (Darmstadt, Germany).

Yeast mutant bioassay: The bioactivity of the crude plant extracts against Saccharomyces 
cerevisiae was determined by the well diffusion method according to Ríos et al. (1988). S. cerevisiae mutant strains RS322N, R52Y and RS321 were supplied by Dr. David G.I. Kingston and were used for the topoisomerase assay. S. cerevisiae strains were cultured in erlenmeyers containing YPD broth. Each microorganism was diluted with a sodium chloride isotonic solution to obtain $25 \%$ of transmittance (optical density at $600 \mathrm{~nm}$ ). One milliliter of this microorganism suspension was thoroughly mixed with $20 \mathrm{~mL}$ of sterile YPD agar in each Petri dish.

After solidification, seven wells $(6.0 \mathrm{~mm}$ diameter each) were made in each plate under sterile conditions. Each well was filled with $20 \mu \mathrm{L}$ of each one of the five different concentrations tested (4 000, $2000,1000,500$ and $250 \mathrm{mg} / \mathrm{L})$ for each plant extract. A volume of $20 \mu \mathrm{L}$ of nystatin at $30,150,40 \mathrm{mg} / \mathrm{L}$ for RS322N, R52Y and RS321 strains, were used as positive control, respectively; $20 \mu \mathrm{L}$ of DMSOEtOH- $\mathrm{H}_{2} \mathrm{O}$ (1:1:2) (for no-polar extracts) and EtOH- $\mathrm{H}_{2} \mathrm{O}$ (1:4) (for polar extracts) were used as negative controls. All plates were incubated at $30^{\circ} \mathrm{C}$ for $24 \mathrm{~h}$. Inhibition zone diameters around each well were measured and recorded at the end of the incubation time. All determinations were performed in triplicate with two replicates, and the mean standard deviations $( \pm \mathrm{SD})$ were obtained with these values. Activity was determined from a dose to response curve and is reported as $\mathrm{IC}_{12}(\mu \mathrm{g} / \mathrm{mL})$ values, which is the concentration required for an extract to produce an inhibition zone of $12 \mathrm{~mm}$ in diameter, around each $6.0 \mathrm{~mm}$ diameter well in this bioassay (Gunatilaka \& Kingston 1998).

In this bioassay, an extract is considered active if it displays selective activity against one or more repair deficient yeast. For instance, an agent that displays greater activity against RS321 rather than to $\mathrm{RS} 322 \mathrm{~N}$, with an $\mathrm{IC}_{12}$ less than one third between both yeast strains and in general if they exhibit an $\mathrm{IC}_{12}$ less than 2000 , most probably mediates its inhibitory activity through topoisomerase II. Conversely, greater activity against RS322N implies an inhibitory
DNA topoisomerase I mechanism (Gunatilaka \& Kingston 1998, Zhou et al. 2000).

Antioxidant activity: The antioxidant activities were measured through the DPPH radical scavenging activity by the method of Brand-Williams et al. (1995), with minor modifications; for example, the $n$-hexane, dichloromethane and aqueous-methanol extracts were dissolved in the same mixtures used in the yeast mutant assay and they were also used as blank in the DPPH assay $\left(\mathrm{A}_{517 \text { Blank}}\right)$. All plant extracts were evaluated at $250 \mathrm{mg} / \mathrm{L}$ by mixing $0.75 \mathrm{~mL}$ of each one with $1.5 \mathrm{~mL}$ of a freshly prepared DPPH solution $(20 \mathrm{mg} / \mathrm{L})$ and stood for 20 minutes under light protection at room temperature $\left(\mathrm{A}_{517}\right.$ Sample $)$. Then, the absorbances were measured at $517 \mathrm{~nm}$ and the percentage of DPPH radical scavenging activity for each plant extract was calculated by applying the equation: $(\mathrm{I} \%)=\left(\mathrm{A}_{517 \text { Blank }}-\mathrm{A}_{517 \text { Sample }) /}\right.$ $\left.\mathrm{A}_{517 \text { Blank }}\right) \mathrm{x} 100$. Each assay was performed in triplicate with two replicates in different times. With these values the mean standard deviations $( \pm \mathrm{SD})$ were calculated.

Phytochemical screening: For each plant extract a phytochemical screening was performed testing the presence of secondary metabolites by using TLC analysis. The solvent systems $n$-hexane-ethyl acetate $(6: 4)$ was used for development of $n$-hexane extracts; while, ethyl acetate-methanol-water (100:13.5:10) was used for elution of dichloromethane and the aqueous-methanol extracts, respectively. The following spray reagents Dragendorff, anisaldehyde-sulphuric acid, $1 \%$ vanillin in sulphuric acid-ethanol, $2 \%$ aluminium chloride in ethanol, $1 \%$ ferric chloride, and hydroxylamine-ferric chloride were used as chromogenic agents for alkaloids, sterols, saponins, flavonoids, tannins and lactones, respectively (Wagner \& Bladt 1996). All determinations were done in duplicates.

\section{RESULTS}

Yeast mutant bioassay: A total of 35 different crude plant extracts ( $n$-hexane, 
TABLE 1

Inhibition concentration ( $\mathrm{IC}_{12} \mu \mathrm{g} / \mathrm{mL}$ ) of 35 crude plant extracts collected at La Marcada Natural Regional Park (LMNRP).

\begin{tabular}{|c|c|c|c|c|c|}
\hline \multirow[t]{2}{*}{ Family } & \multirow[t]{2}{*}{ Species (Voucher number) } & \multirow[t]{2}{*}{ Extract $^{1}$} & \multicolumn{3}{|c|}{$\begin{array}{l}\text { Saccharomyces cerevisiae } \\
\text { strains } \mathrm{IC}_{12}(\mu \mathrm{g} / \mathrm{ml}) \pm \mathrm{SD}\end{array}$} \\
\hline & & & RS322N & R52Y & RS321 \\
\hline \multirow[t]{9}{*}{ Apocynaceae } & \multirow[t]{3}{*}{ Mandevilla veraguensis Hemsl. (FJR 3955) } & $\mathrm{H}^{1}$ & -4 & - & - \\
\hline & & $\mathrm{DC}^{2}$ & - & - & - \\
\hline & & $\mathrm{A}-\mathrm{Mt}^{3}$ & - & - & - \\
\hline & \multirow{3}{*}{$\begin{array}{l}\text { Blepharodon mucronatum (Schltdl.) Decne. } \\
\text { (FJR 3952) }\end{array}$} & $\mathrm{H}$ & - & - & - \\
\hline & & $\mathrm{DC}$ & - & - & - \\
\hline & & $\mathrm{A}-\mathrm{Mt}$ & - & - & - \\
\hline & \multirow{3}{*}{$\begin{array}{l}\text { Mandevilla fendleri (Mull.Arg.) Woodson } \\
\text { (FJR 3951) }\end{array}$} & $\mathrm{H}$ & - & - & - \\
\hline & & $\mathrm{DC}$ & - & - & - \\
\hline & & $\mathrm{A}-\mathrm{Mt}$ & - & - & - \\
\hline \multirow[t]{3}{*}{ Cactaceae } & \multirow[t]{3}{*}{ Rhipsalis micrantha DC (FJR 3948) } & $\mathrm{H}$ & - & - & - \\
\hline & & $\mathrm{DC}$ & - & - & - \\
\hline & & A-Mt & - & - & - \\
\hline \multirow[t]{3}{*}{ Costaceae } & \multirow[t]{3}{*}{ Costus sp. (FJR 3958) } & $\mathrm{H}$ & - & - & - \\
\hline & & $\mathrm{DC}$ & $\mathrm{NE}^{5}$ & $\mathrm{NE}$ & $\mathrm{NE}$ \\
\hline & & A-Mt & - & - & - \\
\hline \multirow[t]{3}{*}{ Eremolepidaceae } & \multirow[t]{3}{*}{ Antidaphne viscoidea Poepp. \& Endl. (FJR 3956) } & $\mathrm{H}$ & - & - & - \\
\hline & & $\mathrm{DC}$ & - & - & - \\
\hline & & $\mathrm{A}-\mathrm{Mt}$ & - & - & - \\
\hline \multirow[t]{6}{*}{ Passifloraceae } & \multirow[t]{3}{*}{ Passiflora suberosa L. (FJR 3954) } & $\mathrm{H}$ & - & - & - \\
\hline & & $\mathrm{DC}$ & - & - & - \\
\hline & & A-Mt & - & - & - \\
\hline & \multirow[t]{3}{*}{ Passiflora rubra L. (FJR 3953) } & $\mathrm{H}$ & - & - & - \\
\hline & & DC & - & - & - \\
\hline & & A-Mt & - & - & - \\
\hline \multirow[t]{3}{*}{ Solanaceae } & \multirow{3}{*}{$\begin{array}{l}\text { Solanum aturense Humb. \& Bonpl. Ex Dunal } \\
\text { (FJR 3947) }\end{array}$} & $\mathrm{H}$ & - & - & - \\
\hline & & $\mathrm{DC}$ & - & - & - \\
\hline & & A-Mt & - & - & - \\
\hline \multirow[t]{12}{*}{ Urticaceae } & \multirow[t]{3}{*}{ Myriocarpa stipitata Benth (FJR 3959) } & $\mathrm{H}$ & $6607 \pm 1$ & $2910 \pm 2$ & $5208 \pm 1$ \\
\hline & & DC & $835 \pm 4$ & $434 \pm 5$ & $1306 \pm 3$ \\
\hline & & A-Mt & - & - & - \\
\hline & \multirow[t]{3}{*}{ Urera baccifera Gaudich (FJR 3957) } & $\mathrm{H}$ & - & - & - \\
\hline & & DC & $\mathrm{NE}$ & $\mathrm{NE}$ & $\mathrm{NE}$ \\
\hline & & $\mathrm{A}-\mathrm{Mt}$ & - & - & - \\
\hline & \multirow[t]{3}{*}{ indet. sp. 1 (FJR 3946) } & $\mathrm{H}$ & - & - & - \\
\hline & & DC & - & - & - \\
\hline & & A-Mt & NE & NE & $\mathrm{NE}$ \\
\hline & \multirow[t]{3}{*}{ Phenax rugosus (Poir.) Wedd. (FJR 3960) } & $\mathrm{H}$ & - & - & - \\
\hline & & $\mathrm{DC}$ & - & - & - \\
\hline & & A-Mt & $\mathrm{NE}$ & $\mathrm{NE}$ & $\mathrm{NE}$ \\
\hline Positive control & & Nystatin & 30 & 150 & 40 \\
\hline $\begin{array}{l}{ }^{1} \mathrm{H}=n \text {-Hexane } ;{ }^{2} \mathrm{I} \\
{ }^{5} \mathrm{NE}=\text { Not evaluat }\end{array}$ & C=Dichloromethane; ${ }^{3} \mathrm{~A}-\mathrm{Mt}=$ Aqueous-methanol $;{ }^{4}$ & $=$ Not activ & & & \\
\hline 1092 & Rev. Biol. Trop. (Int. J. Tro & Biol. ISSN-00 & 7744) Vol. 59 & : 1089-1097 & ptember 201 \\
\hline
\end{tabular}


dichloromethane and aqueous-methanol) were screened for their activity against $S$. cerevisiae strains in the yeast mutant assay. The results are shown in Table 1. The dichloromethane extracts from Myriocarpa stipitata Benth. (Urticaceae) was the only one that showed moderate topoisomerase I activity.

Phytochemical screening: The phytochemical screening of the $n$-hexane, dichloromethane and aqueous-methanol extracts showed the presence of different types of secondary metabolites, namely saponins, tannins, flavonoids and terpenes (Table 2). These phytocompounds were present in almost all the extracts tested. However, M. stipitata (Urticaceae) extracts did not show evidence of flavonoids and Costus sp. (Costaceae) did not display the presence of tannins neither lactones (Table 2).

Antioxidant activity: Table 3 shows the percentage of antioxidant activity from the plant extracts studied. The aqueous-methanol extracts were the most effective in the DPPH assay. But, the $n$-hexane extract of Costus sp. exhibited the highest percentage $(48 \%)$ of antioxidant activity while hydroquinone (the positive control) showed a percentage of $26 \%$.

TABLE 2

TLC phytochemical screening of crude plant extracts collected at La Marcada Natural Regional Park (LMNRP)

\begin{tabular}{|c|c|c|c|c|c|c|c|c|}
\hline \multirow{2}{*}{ Family } & \multirow{2}{*}{ Species } & \multirow{2}{*}{ Extract } & \multicolumn{6}{|c|}{ Phytocompounds } \\
\hline & & & Alkaloids & Terpenes & Flavonoids & Tannins & Saponins & Lactones \\
\hline \multirow[t]{9}{*}{ Apocynaceae } & \multirow{3}{*}{$\begin{array}{l}\text { Mandevilla } \\
\text { veraguensis }\end{array}$} & $\mathrm{H}$ & - & +++ & - & +++ & +++ & - \\
\hline & & $\mathrm{DC}$ & - & ++ & - & +++ & +++ & - \\
\hline & & A-Mt & - & - & +++ & +++ & + & - \\
\hline & \multirow{3}{*}{$\begin{array}{l}\text { Blepharodon } \\
\text { mucronatum }\end{array}$} & $\mathrm{H}$ & - & - & - & - & +++ & - \\
\hline & & $\mathrm{DC}$ & - & + & +++ & - & +++ & - \\
\hline & & A-Mt & - & - & +++ & ++ & + & - \\
\hline & \multirow[t]{3}{*}{ Mandevilla fendleri } & $\mathrm{H}$ & - & +++ & - & - & +++ & - \\
\hline & & $\mathrm{DC}$ & - & ++ & - & + & +++ & - \\
\hline & & A-Mt & - & - & - & - & - & - \\
\hline \multirow[t]{3}{*}{ Cactaceae } & \multirow[t]{3}{*}{ Rhipsalis micrantha } & $\mathrm{H}$ & - & - & - & - & ++ & - \\
\hline & & DC & - & - & - & - & ++ & - \\
\hline & & A-Mt & - & + & - & - & ++ & - \\
\hline \multirow[t]{3}{*}{ Costaceae } & \multirow[t]{3}{*}{ Costus sp. } & $\mathrm{H}$ & - & - & - & - & ++ & - \\
\hline & & $\mathrm{DC}$ & + & +++ & +++ & - & ++ & - \\
\hline & & A-Mt & - & - & +++ & - & - & - \\
\hline \multirow[t]{3}{*}{ Eremolepidaceae } & \multirow[t]{3}{*}{ Antidaphne viscoidea } & $\mathrm{H}$ & - & - & - & +++ & ++ & - \\
\hline & & $\mathrm{DC}$ & $\mathrm{NE}$ & $\mathrm{NE}$ & $\mathrm{NE}$ & $\mathrm{NE}$ & $\mathrm{NE}$ & $\mathrm{NE}$ \\
\hline & & A-Mt & - & - & - & - & ++ & - \\
\hline \multirow[t]{6}{*}{ Passifloraceae } & \multirow[t]{3}{*}{ Passiflora suberosa } & $\mathrm{H}$ & - & +++ & - & +++ & +++ & - \\
\hline & & $\mathrm{DC}$ & + & + & - & ++ & ++ & +++ \\
\hline & & A-Mt & - & - & ++ & - & - & - \\
\hline & \multirow[t]{3}{*}{ Passiflora rubra } & $\mathrm{H}$ & - & - & - & ++ & ++ & - \\
\hline & & DC & - & + & - & ++ & ++ & + \\
\hline & & A-Mt & - & +++ & - & - & +++ & - \\
\hline \multirow[t]{3}{*}{ Solanaceae } & \multirow[t]{3}{*}{ Solanum aturense } & $\mathrm{H}$ & - & - & & + & +++ & ++ \\
\hline & & DC & - & - & - & - & ++ & - \\
\hline & & A-Mt & - & - & ++ & - & - & - \\
\hline
\end{tabular}


TABLE 2 (Continued)

TLC phytochemical screening of crude plant extracts collected at La Marcada Natural Regional Park (LMNRP)

\begin{tabular}{|c|c|c|c|c|c|c|c|c|}
\hline \multirow{2}{*}{ Family } & \multirow{2}{*}{ Species } & \multirow{2}{*}{ Extract } & \multicolumn{6}{|c|}{ Phytocompounds } \\
\hline & & & Alkaloids & Terpenes & Flavonoids & Tannins & Saponins & Lactones \\
\hline \multirow[t]{12}{*}{ Urticaceae } & Myriocarpa stipitata & $\mathrm{H}$ & - & ++ & - & + & ++ & - \\
\hline & & $\mathrm{DC}$ & +++ & - & - & - & ++ & - \\
\hline & & A-Mt & - & - & - & - & + & - \\
\hline & Urera baccifera & $\mathrm{H}$ & - & - & - & - & ++ & ++ \\
\hline & & DC & $\mathrm{NE}$ & $\mathrm{NE}$ & $\mathrm{NE}$ & NE & $\mathrm{NE}$ & $\mathrm{NE}$ \\
\hline & & A-Mt & - & - & - & - & - & - \\
\hline & indet. sp. 1 & $\mathrm{H}$ & - & ++ & - & - & ++ & ++ \\
\hline & & $\mathrm{DC}$ & + & +++ & - & ++ & ++ & - \\
\hline & & A-Mt & $\mathrm{NE}$ & $\mathrm{NE}$ & $\mathrm{NE}$ & $\mathrm{NE}$ & $\mathrm{NE}$ & $\mathrm{NE}$ \\
\hline & Phenax rugosus & $\mathrm{H}$ & - & - & - & - & ++ & ++ \\
\hline & & $\mathrm{DC}$ & - & - & - & - & ++ & - \\
\hline & & A-Mt & NE & $\mathrm{NE}$ & NE & $\mathrm{NE}$ & NE & NE \\
\hline Standards & & & $\begin{array}{c}\text { Papaverine } \\
+++\end{array}$ & $\begin{array}{c}\text { Taxol } \\
+++\end{array}$ & $\begin{array}{c}\text { Kaempferol } \\
+++\end{array}$ & $\begin{array}{c}\text { Gallic } \\
\text { Acid } \\
+++\end{array}$ & $\begin{array}{c}\text { Digitonin } \\
+++\end{array}$ & $\begin{array}{c}\text { Digitoxin } \\
+++\end{array}$ \\
\hline
\end{tabular}

${ }^{1} \mathrm{H}=n$-Hexane; ${ }^{2} \mathrm{DC}=$ Dichloromethane; ${ }^{3} \mathrm{~A}-\mathrm{Mt}=$ Aqueous-methanol.

$(-)=$ Absent; $(+)=$ Weak content; $(++)=$ Moderate content; $(+++)=$ Strong content; NE=Not evaluated.

TABLE 3.

Percentage of antioxidant activity from the plant extracts studied

\begin{tabular}{|c|c|c|c|c|}
\hline \multirow{2}{*}{ Family } & \multirow{2}{*}{ Species } & \multicolumn{3}{|c|}{ Percentage of antioxidant activity \pm SD * } \\
\hline & & $n$-Hexane & Dichloromethane & Aqueous-methanol \\
\hline \multirow{3}{*}{ Apocynaceae } & Mandevilla fendleri & - & $18 \pm 1.8$ & $14 \pm 1.4$ \\
\hline & Blepharodon mucronatum & - & - & $17 \pm 2.8$ \\
\hline & Mandevilla veraguensis & - & - & $18 \pm 2.2$ \\
\hline Cactaceae & Rhipsalis micrantha & - & $29 \pm 1.6$ & $21 \pm 1.5$ \\
\hline Costaceae & Costus sp. & $48 \pm 2.4$ & NE & - \\
\hline Eremolepidaceae & Antidaphne viscoidea & - & - & $13 \pm 1.7$ \\
\hline \multirow[t]{2}{*}{ Passifloraceae } & Passiflora suberosa & - & - & - \\
\hline & Passiflora rubra & - & - & - \\
\hline Solanaceae & Solanum aturense & - & $22 \pm 1.5$ & $22 \pm 1.3$ \\
\hline \multirow[t]{4}{*}{ Urticaceae } & Myriocarpa stipitata & - & $19 \pm 1.8$ & $20 \pm 1.2$ \\
\hline & Urera baccifera & - & NE & - \\
\hline & indet. sp. 1 & - & - & $\mathrm{NE}$ \\
\hline & Phenax rugosus & - & - & $\mathrm{NE}$ \\
\hline Control & Hydroquinone & & 26 & \\
\hline
\end{tabular}

*Values are the mean of triplicate readings; $(-)=$ Not active; $\mathrm{NE}=$ Not evaluated 


\section{DISCUSSION}

Since the crude dichloromethane extract from $M$. stipitata (Urticaceae) showed an $\mathrm{IC}_{12}$ against the RS322N strain $(835 \pm 4 \mu \mathrm{g} / \mathrm{mL})$ rather than to RS321 strain $(1306 \pm 3 \mu \mathrm{g} / \mathrm{mL})$, this implies that this plant extracts showed moderate DNA topoisomerase I inhibitory activity; the other plant extracts did not show any DNA topoisomerase I or II inhibitory activity at all. The last results correlate for instance, with the extract of some Cactaceae species (Rhipsalis baccifera (Mill.) Stearn and Rhipsalis mesembryanthemoides Steud.) that were not active against any of $S$. cerevisiae strains assayed (Valente et al. 2007).

The result with $M$. stipitata is in concordance with those found for the antineoplastic activity from Boehmeria siamensis Craib (Urticaceae), because both plants contain alkaloid. From B. siamensis has been isolated the phenanthroquinolizidine type alkaloids boehmeriasin $\mathrm{A}$ and $\mathrm{B}$, and the latter one showed antitumor activity as evidenced by an in vitro bioassay (Luo et al. 2003, Yan et al. 2006). According to the phytochemical screening (Table 2), it can be deduced that the biological activity showed by the crude dichloromethane extract from M. stipitata could be attributed to phytocompounds such as alkaloid or saponin present on this extract. The relevance of DNA topoisomerase I inhibitory activity displayed by $M$. stipitata extract is based on the fact that there are not reports on the phytocompounds neither on the biological activity for this species or genus in the yeast mutant assay (Dyer et al. 2003).

Furthermore, these results on the DPPH assay suggest that the $n$-hexane extract from Costus sp. is a powerful natural antioxidant and according to the phytochemical screening this activity could be explained based on its saponin contents. From Costus speciosus SM. and Costus spicatus $\mathrm{Sw}$. (Costaceae) there has been isolated a series of furostanol saponins (Sigh \& Thakur 1982, Da Silva et al. 1999) which could explain their in vitro antioxidant activity.
Recently, interest has increased considerably in finding saponins with antioxidant properties. They have been described as antioxidant agents against free radical mediated cellular damage (Somova et al. 2003, Garcez et al. 2006, Dini et al. 2009), inhibitors of membrane lipid peroxidation (Yoshiki et al. 1996, Keum et al. 2000) and protection against low density lipoproteins oxidation (Li et al. 2008).

In addition, the antioxidant activity of Rhipsalis micrantha DC (Cactaceae) correlates well with the antioxidant activities of Opuntia ficus-indica (L.) Mill.; however, in the last species this activity could be explained based on its flavonoid contents such as quercetin and myricetin present in their extracts (Lee et al. 2002); while in the former one this activity could not be explained based on its flavonoids contents, since in our phytochemical screening this type of phytocompounds were not detected.

On the other hand, the aqueous-methanol extract from Mandevilla veraguensis Hemsl. (Apocynaceae) showed a moderate percentage of antioxidant activity. This result is in concordance with the rate and the antioxidant activity displayed by Holarrhena pubescens Wall. (Apocynaceae) in the total antioxidant in vitro assay (Palasuwan et al. 2005), and with a moderate antioxidant activity of aqueous extract from Mandevilla pentlandiana (A.DC) Woodson (Borneo et al. 2009); furthermore, Rauvolfia sellowii Müll. Arg. (Apocynaceae) also displayed good scavenging activity in the DPPH test (Menezes et al. 2004). Moreover, the aqueous-methanol extract from Solanum aturense Humb. \& Bonpl. Ex Dunal (Solanaceae) also showed a moderate percentage of antioxidant activity and this result correlates with the high antioxidant activity exhibited by the methanol extracts of Solanum nigrum L. fruits in the DPPH assay (Al-Fatimi et al. 2007).

Our results suggest that the crude dichloromethane extracts from Myriocarpa stipitata (Urticaceae) and Rhipsalis micrantha (Cactaceae), as well as the $n$-hexane extract from Costus sp. (Costaceae) showed good bioactivity that provide evidence related to the potentiality from the LMNRP flora in the 
search for novel antioxidant compounds. In addition, the fact that the dichloromethane extract from M. stipitata (Urticaceae) displayed topoisomerase I inhibition is a good argument in the search of anticarcinogenic agents from plant sources. Further research is needed to isolate the compounds responsible for these biological activities.

\section{ACKNOWLEDGMENTS}

The authors would like to thank the Universidad Tecnológica de Pereira for the financial support to the project, and to the Corporación Autónoma Regional de Risaralda (CARDER) for granting permission to access plant collection. The authors also wish to thank to D.G.I. Kingston, of the Chemistry Department, Virginia Polytechnic Institute and State University (VA, USA) for providing the yeast strains used in this work.

\section{RESUMEN}

Desde tiempos inmemoriales, muchas plantas han sido usadas para el tratamiento de varias enfermedades e infecciones, este potencial ha sido explotado por la industria farmacéutica en la búsqueda de nuevos agentes analgésicos, anticancerígenos y antimicrobianos, entre otros. Consientes con esto, se evaluó la actividad de 35 extractos de 13 especies de plantas recolectadas en el Parque Regional Natural La Marcada (PRNLM, Colombia) contra las cepas mutadas de Saccharomyces cerevisiae RS322N, R52Y y RS321 en el ensayo de la levadura mutada y la capacidad antioxidante de los extractos a través del método del DPPH. El extracto crudo de diclorometano de Myriocarpa stipitata (Urticaceae) presentó actividad moderada contra las tres cepas de $S$. cerevisiae evaluadas. Lo cual permitió inferir la capacidad del extracto de diclorometano de esta especie para inhibir la enzima topoisomerasa I y causar daño al ADN. Además, en el ensayo del DPPH, el extracto de $n$-hexano crudo de Costus sp (Costaceae) mostró actividad antioxidante buena (48\%), mientras que los extractos de diclorometano y acuoso metanólico crudos de Rhipsalis micrantha (Cactaceae) tuvieron actividad antioxidante moderada, con valores del 29 y $21 \%$, respectivamente.

Palabras clave: agentes que dañan elADN, DPPH, inhibidores de las ADN topoisomerasas, Saccharomyces cerevisiae.

\section{REFERENCES}

Al-Fatimi, M., M. Wurster, G. Schröder \& U. Lindequist. 2007. Antioxidant, antimicrobial and cytotoxic activities of selected medicinal plants from Yemen. J. Ethnopharmacol. 111: 657-666.

Borneo, R., A.E. León, A. Aguirre, P. Ribotta \& J.J. Cantero. 2009. Antioxidant capacity of medicinal plants from the Province of Córdoba (Argentina) and their in vitro testing in a model food system. Food Chem. 112: 664-670.

Brand-Williams, W., M. Cuvelier \& C. Berset. 1995. Use of a free radical method to evaluate antioxidant activity. Lebenson Wiss Technol. 28: 25-30.

Colley, W., M. Van der Merwe, J. Vance, A. Burgin \& M. Bjornsti. 2004. Substitution of conserved residues within the active site alters the cleavage religation equilibrium of DNA topoisomerase I. J. Biol. Chem. 279: 54069-54078.

Da Silva, B.P., R.R. Bernardo \& J.P. Parente. 1999. A furostanol glycoside from rhizomes of Costus spicatus. Phytochemistry 51: 931-935.

Dini, I., G.C. Tenore \& A. Dini. 2009. Saponins in Ipomoea batatas tubers: isolation, characterization, quantification and antioxidant properties. Food Chem. 113: 411-419.

Dong, J., J. Walker \& J. Nitiss. 2000. A mutation in yeast topoisomerase II that confers hypersensitivity to multiple classes of topoisomerase II poisons. J. Biol. Chem. 275: 7980-7987.

Dyer, L.A., C.D. Dodson \& G. Gentry. 2003. A bioassay for insect deterrent compounds found in plant and animal tissues. Phytochem. Anal. 14: 381-388.

Garcez, R.F., S.W. Garcez, A.L.B.D. Santana, M.M. Alves, M.F.C.C. Matos \& A.M. Scaliante. 2006. Bioactive flavonoids and triterpenes from Terminalia fagifolia (Combretaceae). J. Braz. Chem. Soc. 17: 1223-1228.

Gasparri, S. 2005. Estudo das atividades antioxidante e mutagênica/antimutagênica induzida pelo extracto vegetal da Costus spicatus. Dissertação de Mestrado. Universidade Luterana do Brasil, Canoas, Brasil.

Gunatilaka, A.A.L. \& D.G.I. Kingston. 1998. DNAdamaging natural products with potential anticancer activity. In Atta-ur-Rhahman (ed.). Studies in natural products chemistry. Elsevier, Amsterdam, Netherlands.

Keum, Y.S., K.K. Park, J.M. Lee, K.S. Chun, J.H. Park, S.K. Lee, H. Kwon \& Y.J. Surh. 2000. Antioxidant 
and anti-tumor promoting activities of the methanol extract of heat-processed ginseng. Cancer Lett. 150: 41-48.

Lee, J.C., H.R. Kim, J. Kim \& Y.S. Jang. 2002 . Antioxidant property of an ethanol extract of the stem of Opuntia ficus-indica var. Saboten. J. Agric. Food Chem. 50: 6490-6496.

Li, H., Q.J. Wang, D.N. Zhu \& Y. Yang. 2008. Reinioside C, a triterpene saponin of Polygala aureocauda Dunn, exerts hypolipidemic effect on hyperlipidemic mice. Phytother. Res. 22: 159-164.

Luo, Y., Y. Liu, D. Luo, X. Gao, G. Li \& G. Zhang. 2003. Cytotoxic alkaloids from Bohemeria siamensis. Planta Med. 69: 842-845.

Menezes, P.R., E.A. Schwarz \& C.A.M. Santos. 2004. In vitro antioxidant activity of species collected in Paraná. Fitoterapia 75: 398-400.

Moon, J.K. \& T. Shibamoto. 2009. Antioxidant assay for plant and food components. J. Agric. Food Chem. 57: 1655-1666.

Niño, J., G.M. Hincapie, Y.M. Correa \& O.M. Mosquera. 2007. Alkaloids of Crinum x powellii "Album" (Amaryllidaceae) and their topoisomerase inhibitory activity. Z. Naturforsch. c 62c: 223-226.

Palasuwan, A., S. Soogarun, T. Lertlum, P. Pradniwat \& V. Wiwanitkit. 2005. Inhibition of heinz body induction in an in vitro model and total antioxidant activity of medicinal Thai plants. Asian Pac. J. Cancer Prev. 6: 458-463.

Rajeshkumar, N.V., K.L. Joy, G. Kunattan, R.S. Ramsewak, M. Nair \& R. Kuttan. 2002. Antitumor and anticarcinogenic activity of Phyllanthus amarus extract. J. Ethnopharmacol. 81: 17-22.

Ramirez-Mares, M., S. Chandra \& E. Gonzales. 2004. In vitro chemopreventive activity of Camelia sinensis, Ilex paraguariensis and Ardisia compressa tea extracts and selected polyphenols. Mutat. Res. 554: 53-65.

Reddy, B.S., R.K.K. Reddy, V.G.M. Naidu, K. Madhusudhana, S.B. Agwane, S. Ramakrishna \& P.V. Diwan. 2008. Evaluation of antimicrobial, antioxidant and wound-healing potentials of Holoptelea integrifolia. J. Ethnopharmacol. 115: 249-256.
Ríos, J.L., M.C. Recio \& A. Villar. 1988. Screening methods for natural products with antimicrobial activity: A review of the literature. J. Ethnopharmacol. 23: $127-149$.

Sigh, S.B. \& R.S. Thakur. 1982. Coustusoside-I and coustusoside-J, two new furostanol saponin from the seeds of Costus speciosus. Phytochemistry 21: 911-915.

Simon, J., P. Szankasi, D. Nguyen, C. Ludlow, H. Dunstan, C. Roberts, E. Jense, L. Hartwell \& S. Friend. 2000. Differential toxicities of anticancer agents among DNA repair and checkpoints mutants of Saccharomyces cerevisiae. Cancer Res. 60: 328-333.

Somova, L.O., A. Nadar, P. Rammanan \& F.O. Shode. 2003. Cardiovascular, antihyperlipidemic and antioxidant effects of oleanolic and ursolic acids in experimental hypertension. Phytomedicine 10: 115-121.

Valente, L.M.M., L.A. Scheinvar, G.C. Da Silva, A.P. Antunes, F.A.L. dos Santos, T.F. Oliveira, M.R.R. Tappin, F.R. Aquino Neto, A.S. Pereira, S.F. Carvalhae, A.C. Siani, R.R. dos Santos, R.O.A. Soares, E.F. Ferreira, M. Bozza, C. Stutz \& D. Gibaldi. 2007. Evaluation of the antitumor and trypanocidal activities and alkaloid profile in species of Brazilian Cactaceae. Phcog. Mag. 11: 167-172.

Wagner, H. \& S. Bladt. 1996. Plant Drug Analysis. A thin layer chromatography atlas. Springer-Verlag, Berlin, Germany.

Yan, J., D. Luo, Y. Luo, X. Gao \& G. Zhang. 2006. Induction of G1 arrest and differentiation in MDAMB-231 breast cancer cell by boehmeriasin A, a novel compound from plant. Int. J. Gynecol. Cancer 16: $165-170$.

Yoshiki, M., Y. Okubo, K. Seto \& J.Y. Sasaki. 1996. Prevention of hydrogen peroxide damage by soybean saponins to mouse fibroblasts. Planta Med. 62: 252-255.

Zhang, H. \& W. Siede. 2003. Validation of a novel assay for checkpoint responses: characterization of camptothecin derivatives in Saccharomyces cerevisiae. Mutat. Res. 527: 37-48.

Zhou, B., R. Johnson, M. Mattern, X. Wang, S. Hecht, H. Back, A. Ortiz \& D. Kingston. 2000. Isolation and biochemical characterization of a new topoisomerase I inhibitor from Ocotea leucoxylon. J. Nat. Prod. 63: $217-222$. 